\title{
PNEUMOSINUS DILATANS - A RARE DISORDER OF PARANASAL SINUSES
}

\section{Sanu P Moideen ${ }^{* 1}$, Cini P Moideen ${ }^{2}$, Shaik Mohammed Muaz ${ }^{3}$.}

${ }^{* 1}$ Senior Resident, Department of Pediatric Otorhinolaryngology, Christian Medical College, Vellore, Tamil Nadu, India.

2 Junior resident, Department of Periodontics, Mar Basalious Dental College, Kothamangalam, Kerala, India.

${ }^{3}$ Department of Emergency Medicine, Sri Siddhartha Medical College, Tumakuru, Karnataka, India.

\section{ABSTRACT}

Pneumosinus dilatans is a very rare disorder of the paranasal sinuses, most commonly affecting the frontal sinuses (Pneumosinus dilatans frontalis). So far only 134 cases are reported in the literature. The exact etiology of this disorder is unknown. The pathology causes abnormal dilatation of paranasal sinuses. Most patients are asymptomatic while others can have clinical features of frontal bossing, head ache, visual defects etc. The diagnosis is by computed tomographic imaging. We here report a case of pneumosinus dilatans frontalis in a 22 year old male patient presented with nasal obstruction.

KEY WORDS: Pneumosinus, Frontal Sinus, Paranasal Sinuses, Frontal Bossing, Paranasal Sinus Imaging.

Address for Correspondence: Dr. Sanu P Moideen, MBBS, MS. Pulinganal, Kizhakkekara, Muvattupuzha, Kerala, India 686661. Mobile No: +91-9496336479

E-Mail:drsanu85@gmail.com

Access this Article online

Quick Response code

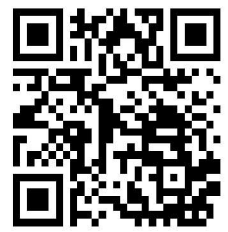

DOI: $10.16965 /$ ijar.2018.112

Journal Information

International Journal of Anatomy and Research

ICV for 2016 ISSN (E) 2321-4287 | ISSN (P) 2321-8967

90.30 https://www.ijmhr.org/ijar.htm DOI-Prefix: https://dx.doi.org/10.16965/ijar

Article Information

Received: 08 Jan 2018

Peer Review: 08 Jan 2018

Revised: None
Accepted: 03 Feb 2018

Published (O): 05 Mar 2018

Published (P): 05 Mar 2018

\section{INTRODUCTION}

Pneumosinus dilatans is a rare disorder of paranasal sinuses with unknown etiology. The disease is characterized by pathological expansion of paranasal sinuses which contains only air and lined with normal sinus mucosa. This can involve only a single sinus or multiple sinuses. Meyes first described about this disease in 1898 and labelled it pneumatocoele, but it was Benjamin who assigned the name Pneumosinus dilatans for this disorder in 1918 [1,2]. The disease most frequently affects the frontal sinuses, followed by sphenoid sinuses, maxillary sinuses and ethmoidal cells [2-4].

Previously, various terms have been used for this pathology, like pneumosinus frontalis, pneumocoele, pneumatocoele, aerocoele, sinus hypertrophy, hyper-pneumatisation, sinus ectasia and sinus blistering etc. In 1987, Urken et al suggested a classification system based on radiological enlargement, wall erosion and clinical symptoms [5]. He classified them into hypersinus, pneumosinus dilatans and pneumocoele. Hypersinus is an asymptomatic aerated paranasal sinus with normal walls confined to the normal boundaries. Pneumosinus dilatans is symptomatic aerated sinus which expands beyond the normal boundaries with normal and intact walls. Pneuomecoele is an aerated sinus with thinning off or a defect in the wall of sinus 
and/or loss of integrity of bone. When the dilatation involves multiple sinuses and mastoid air cells also, the condition is termed pneumosinus dilatans multiplex [1].

As mentioned earlier, frontal is the most commonly involved sinus. A total of 134 cases of pneumosinus frontalis has been described in literature in 117 articles[6]. Here we are presenting a case of pneumosinus dilatans frontalis in a 22-year-old male to add some contribution to literature because of the rarity of this condition.

\section{CASE REPORT}

A 22-year-old male patient presented to department of ENT with right side nasal obstruction for 2 years. The obstruction was insidious in onset and gradually progressive in nature, usually persisting throughout the day. The obstruction aggravates following episodes of cold or upper respiratory tract infections. He also gives history of intermittent nasal discharge which was non-foul smelling and non-blood tinged. There was no history of head ache, fever or facial pain. On anterior rhinoscopic examination, there was right side nasal septal deviation and left inferior turbinate hypertrophy. Diagnostic nasal endoscopy was performed which showed a deviated nasal septum with sharp septal spur on right side at the nasal valve area. Computed tomography (CT) of paranasal sinuses confirmed the diagnosis and also revealed abnormally dilated bilateral frontal sinuses almost extending up to parietal bones (Figure -1). Bilateral extensive pneumatization of sphenoid sinus was also noted involving both pterygoid bones (lateral recess of sphenoid). There were no signs of pathologies inside any sinuses.
After necessary workups, septoplasty under general anesthesia was done for the patient. The surgery and post-operative periods were uneventful and the patient was discharged on $2^{\text {nd }}$ post op day with oral antibiotics, analgesics, antihistamines for 5 days. Follow up at 1 week, 3 months and 6 months were successful and the patient was symptom free.

\section{DISCUSSION}

Pneumosinus dilatans is often an incidental radiologic finding. Most of the time the patients are asymptomatic. Symptomatic presentation includes cosmetic deformity, facial asymmetry, head ache, ocular and visual problems etc $[6,7]$. The most common symptomatic presentation is frontal bossing and prominence of supraorbital ridge [7].

The etiopathogenesis of pneumosinus dilatans is unknown. In general, they are classified into primary (idiopathic) and secondary types. Various hypothesis has been postulated for etiology of primary pneumosinus dilatans. These includes hormonal imbalance, infection with gas forming organisms, spontaneously discharging mucocele etc. The most accepted theory is a one-way (ball) valve effect supported by presence of polypoid mucus in drainage pathway of affected sinuses [1]. Recently in 2014, Jankowsky et al suggested osteogenic diseases as the etiology of primary pneumosinus dilatans. [8].

The secondary types are syndromic, due to compensatory over development of sinuses in association with agenesis of brain (e.g. as in cranio-cerebral hemiatrophy [9]) or due to reduced intracranial pressure [10].

Fig. 1: Radiological Images of Pneumosinus Dilatans - (A) Coronal cuts showing hyperpneumatisation of Frontal sinuses (B) -Coronal cut showing pneumatisation extending laterally above the orbits involving the parietal bones (C) - Axial cut showing bulging left frontal sinus.
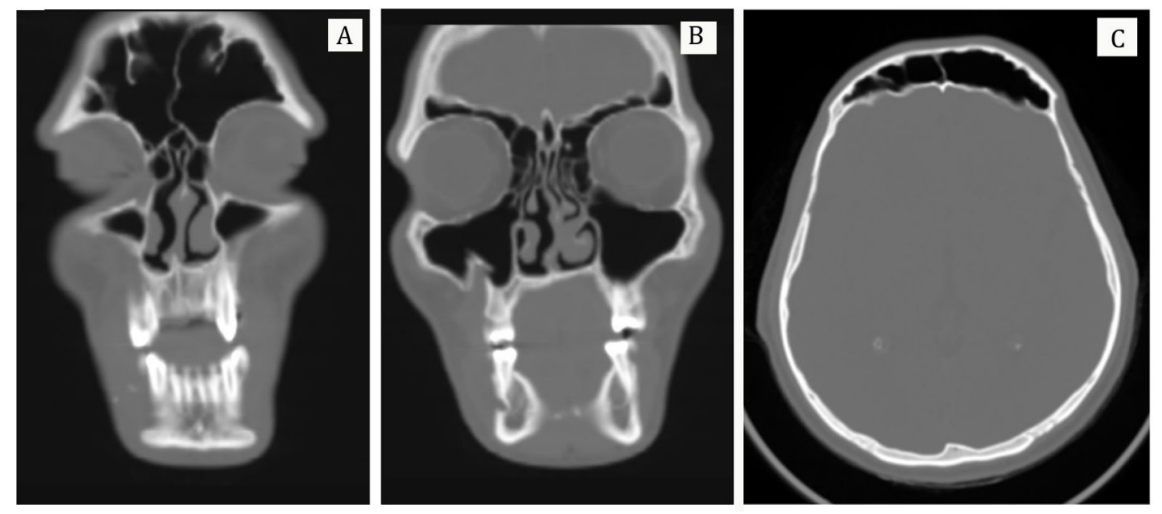
Few cases are reported in association with Melnick Needles Syndrome [11], KlippelTrenaunay-Weber syndrome [12], mental retardation, facial deformity and arachnoid cysts $[1,13]$.

Pneumosinus dilatans is diagnosed with standard radiography or CT Scan of nose and paranasal sinuses. The $\mathrm{CT}$ findings suggestive of pneumosinus dilatans are - enlarged sinus, thinning of the sinus wall, hyperaeration, hyperlucency, bony dehiscence, expansion of recesses, effacement of the ethmomaxillary angle and displacement of the middle meatus[1]. Afroze et al in their report labelled the characteristic radiological finding as as a deer horn pattern when the pneumatization extends to the parietal bones [14]. Magnetic resonance imaging (MRI) and Nasal endoscopic examination ate needed to exclude concomitant intracranial lesions like meningocele, meningoencephalocele, CSF rhinorrhea and chronic rhinosinusitis.

No treatment is needed in asymptomatic patients of pneumosinus. In symptomatic patients of frontal pneumosinus dilatans, surgical correction with a craniofacial repair of malformation is recommended $[1,13,15]$. Several authors have published different surgical techniques and approaches. The most commonly performed procedure is creation of a nasoantral window, to equilibrate the intrasinus pressure [7]. Literature has no reports on recurrence in treated lesions.

\section{CONCLUSION}

Pneumosinus dilatans is a rare disorder of paranasal sinuses which every radiologist, oto-rhino-laryngologists, maxillofacial and plastic surgeon needs to be aware of. The etiology of pneumosinus dilatans remains unclear. Imaging studies are needed for the diagnosis and for differentiating between pneumosinus dilatans and pneumocoeles. Management of symptomatic patients is by surgical exploration of the sinus and recontouring of the anterior table of the frontal sinus.

\section{Conflicts of Interests: None}

\section{REFERENCES}

[1]. Teh BM, Hall C, Chan SW. Pneumosinus dilatans, pneumocoele or air cyst? A case report and literature review. J Laryngol Otol. 2012;126(01):88-93.
[2]. Tovi, F., Gatot, A., Fliss, DM. Air cyst of the maxillary sinus (pneumosinus dilatans, pneumocoele). J Laryngol Otol. 1991;105: 673-5.

[3]. Hirst, LW., Miller, NR., Hodges, FJ III. et al. Sphenoid pneumosinus dilatans. A sign of meningioma originating in the optic canal. Neuroradiology 1982; 22: 207-10.

[4]. Reicher, MA., Bentson, JR., Halbach, VV. et al. Pneumosinus dilatans of the sphenoid sinus. Am J Neuroradiol. 1986; 7: 865-8.

[5]. Urken M, Som P, Lawson W, Edelstein D, Weber A, Biller $\mathrm{H}$. Abnormally large frontal sinus. II. Nomenclature, pathology, and symptoms. Laryngoscope 1987;97:606-11

[6]. Ricci JA. Pneumosinus Dilatans: Over 100 Years without an Etiology. J Oral Maxillofac Surg. 2017 Feb 21.

[7]. Bouguila J, Rejeb MB, Omezzine M, Mani R, Khochtali H. Pneumosinus Dilatans: Rare Cause of Slowly Changing Frontal Contours. Aesthet Surg J. 2015 Mar 1;35(3):NP47-53.

[8]. Jankowski R, Kuntzler S, Boulanger N, Morel O, Tisserant J, Benterkia N, Vignaud JM. Is pneumosinus dilatans an osteogenic disease that mimics the formation of a paranasal sinus?. Surg Radiol Anat. 2014 Jul 1;36(5):429-37.

[9]. Dyke CG, Davidoff LM, Masson CB. Cerebral hemiatrophy with homolateral hypertrophy of the skull and sinuses. Surg Gynecol Obstet 1933;57:588-600.

[10]. Van Schayck R, Niedeggen A. Pneumosinus dilatans after prolonged cerebrospinal fluid shunting in young adults with cerebral hemiatrophy. A report of two cases and review of the literature. Neurosurg Rev 1992;15:217-23.

[11]. Spoor T, Kennerdell J, Maroon J, Hepler R, Krohel G.Pneumosinus dilatans, Klippel-Trenaunay-Weber syndrome, and progressive visual loss. Ann Ophthalmol 1981;13:105-8 Sener R. Arachnoid cysts and pneumosinus dilatans. Comput Med Imaging Graph 1997;21:125-9.

[12]. Martin A, Jarosz J, Thomas N. The strange association of pneumosinus dilatans and arachnoid cyst: case report and review of the literature. Acta Neurochir (Wien) 2001;143:197-201.

[13]. Appelt EA, Wilhelmi BJ, Warder DE, Blackwell SJ. A rare case of pneumosinus dilatans of the frontal sinus and review of the literature. Ann Plast Surg 1999;43:653-6.

[14]. Afroze KH, Suresh BS, Lakshmiprabha S. Pneumo sinus Dilatans Frontalis- A Rare Anatomical Variation of Frontal Sinus. International Journal of Anatomy Radiology and Surgery 2017;6(3): AC01AC02.

[15]. Pospisil OA, Balmer MC. Pneumosinus dilatans. Br J Oral Maxillofac Surg 1998;26:375-80.

How to cite this article: Sanu P Moideen, Cini P Moideen, Shaik Mohammed Muaz. PNEUMOSINUS DILATANS - A RARE DISORDER OF PARANASAL SINUSES. Int J Anat Res 2018;6(1.3):5054-5056. DOI: 10.16965/ijar.2018.112 